\title{
Inovasi Video Pembelajaran Berbantuan Aplikasi Powtoon pada Materi Keliling dan Luas Bangun Datar
}

\author{
A Trisna Sari Asih ${ }^{1}$, Kd Yudiana ${ }^{2}$, Pt Rahayu Ujianti ${ }^{3}$ \\ 1,2 Program Studi Pendidikan Guru Sekolah Dasar, Universitas Pendidikan Ganesha, Singaraja, Indonesia \\ ${ }^{3}$ Program Studi Pendidikan Guru Pendidikan Anak Usia Dini, Universitas Pendidikan Ganesha, Singaraja, Indonesia
}

\section{ART I C L E I N F O}

\section{Article history:}

Received July 06, 202

Revised July 15, 2021

Accepted September 30, 2021

Available online October 25, 2021

\section{Kata Kunci:}

Video Pembelajaran,

Matematika, Powtoon

\section{Keywords}

Learning Video, Mathematics, Powtoon

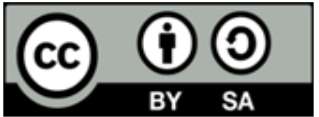

This is an open access article under the CC BY-SA license.

Copyright () 2021 by Author. Published by Universitas Pendidikan Ganesha.

\begin{abstract}
A B S T R A K
Permasalahan yang ditemukan setelah melakukan observasi di sekolah sasaran, antara lain rendahnya tingkat pemahaman siswa terhadap pembelajaran Matematika, motivasi belajar Matematika siswa menurun, siswa menganggap Matematika sebagai pelajaran yang sulit dan menakutkan, serta terbatasnya media pembelajaran daring, khususnya untuk pelajaran Matematika. Penelitian ini bertujuan untuk menghasilkan video pembelajaran dengan berbantuan aplikasi Powtoon pada pembelajaran Matematika, khususunya materi keliling dan luas bangun datar di kelas IV sekolah dasar. Penelitian ini merupakan penelitian pengembangan dengan menggunakan model ADDIE sebagai pedoman. Subjek dalam penelitian ini adalah video pembelajaran berbantuan aplikasi Powtoon pada materi keliling dan luas bangun datar di kelas IV sekolah dasar. Metode pengumpulan data dalam penelitian ini menggunakan kuesioner semi tertutup dalam bentuk skala likert, dengan rentang skala 5 . Teknik analisis data digunakan adalah teknik analisis deskriptif kuantitatif. Hasil uji validitas ahli media diperoleh persentase sebesar 97,7\%. ahli materi diperoleh persentase validitas sebesar 93,3\%, dan uji validitas respon guru diperoleh persentase sebesar 96,6\%. Dari hasil analisis uji validitas tersebut, dapat dikualifikasikan dalam kategori sangat baik. Jadi, dapat disimpulkan bahwa video pembelajaran berbantuan aplikasi Powtoon pada materi keliling dan luas bangun datar di kelas IV sekolah dasar yang dikembangkan dinyatakan telah layak dan valid untuk menunjang proses belajar mengajar.
\end{abstract}

\section{A B S TRACT}

The problems found after observing the target schools include the low level of students' understanding of learning Mathematics, decreased students' motivation to learn Mathematics, students perceive Mathematics as a difficult and intimidating subject, and limited online learning media, especially for Mathematics. This study aims to produce a learning video assisted by Powtoon application on Mathematics subject, especially the perimeter and area of plane figure materials in the fourth grade of elementary school. This study is development research that using the ADDIE model as a guide. The subjects in this study is learning video assisted by Powtoon application on perimeter and area of plane figure materials in the fourth grade of elementary school. The data collection method in this study used a semi-closed questionnaire in the form of a Likert scale, with a scale range of 5 . The data analysis technique used is quantitative descriptive analysis technique. The results of the media expert validity test obtained percentage $97.7 \%$, material experts obtained percentage of validity $93.3 \%$, and the teacher's response validity test obtained percentage $96.6 \%$. From the results of the validity test analysis, it can be qualified in the very good category. So, it can be concluded that the learning video assisted by Powtoon application on the perimeter and area of plane figures materials in the fourth grade of elementary school that developed is feasible and valid to support the teaching and learning process.

\section{PENDAHULUAN}

Kemampuan dan potensi yang dimiliki setiap individu tentunya berbeda-beda antar satu dengan yang lainnya. Melalui pendidikan potensi dan kemampuan tersebut dapat dikembangkan secara lebih optimal. Potensi yang dikembangkan melalui pendidikan tidak hanya dari segi pengetahuan saja, namun juga dari segi sikap, kepribadian, serta keterampilan yang dimiliki setiap individu juga diperhatikan. Pendidikan harus dijadikan prioritas utama sebagai langkah besar untuk memperbaiki masa depan Indonesia (Megawanti, 2015; U.S, 2015). Hal ini karena melalui pendidikan akan tercipta sumber daya manusia yang berkualitas dan mampu memajukan 
bangsanya. Dalam rangka meningkatkan mutu pendidikan telah banyak upaya dan kebijakan yang diberlakukan oleh pemerintah. Namun, pendidikan bukan hanya tanggung jawab pemerintah dan lembaga pendidikan semata, tetapi juga menjadi tanggung jawab bersama termasuk masyarakat (Astawa, 2017). Pada situasi pandemi Covid19 yang sedang melanda berbagai negara, pemerintah Indonesia berupaya menekan penyebaran Covid-19 dengan memberlakukan kebijakan-kebijakan yang menimbulkan dampak di berbagai bidang kehidupan masyarakat, tidak terkecuali di bidang pendidikan (Putria et al., 2020; Wulandari \& Agustika, 2020). Demi menekan penyebaran Covid-19 tanpa mengganggu proses belajar mengajar, pemerintah menerapkan sistem pembelajaran baru dan sekolah-sekolah ditutup untuk sementara. Sistem pembelajaran di sekolah dialihkan dari yang mulanya tatap muka secara langsung (luring) menjadi pembelajaran jarak jauh secara online (daring) (Abidin et al., 2020; Handayani \& Irawan, 2020; Mishra et al., 2020; Oyedotun, 2020; Sahu, 2020).

Diberlakukannya sistem pembelajaran daring atau dalam jaringan ini tentunya menimbulkan dampak yang besar terhadap proses belajar mengajar yang berlangsung. Guru dan siswa tidak lagi dapat berinteraksi secara langsung di sekolah, melainkan hanya dapat berkomunikasi menggunakan bantuan teknologi informasi, seperti Whatsapp, Zoom, Google Meet, Google Classroom dan lain sebagainya yang tentunya memerlukan perangkat pendukung berupa handphone atau laptop dan akses jaringan internet yang memadai (Chang et al., 2020; Hulukati et al., 2021; Putria et al., 2020; Sugandi et al., 2020). Sisi positif yang didapat dari penerapan pembelajaran daring ini adalah tidak adanya batasan ruang maupun waktu dalam belajar, serta dapat menghemat waktu dan biaya transportasi (Anugrahana, 2020; Fauzy \& Nurfauziah, 2021; Hwang et al., 2020). Matematika merupakan salah satu mata pelajaran wajib yang dipelajari siswa disetiap jenjang pendidikan, termasuk di sekolah dasar. Sehingga dapat diketahui Matematika merupakan mata pelajaran yang memegang peranan penting dalam bidang pendidikan (Crismono, 2017; Nugrawati et al., 2018). Matematika juga berkaitan dengan berbagai ilmu pengetahuan dan berbagai aspek kehidupan manusia (Muhtadi et al., 2017; Sumiati \& Agustini, 2020). Dalam mengikuti proses pembelajaran Matematika siswa diharapkan mampu memahami dan mengaplikasikan prinsip Matematika dalam kehidupannya sehari-hari, sehingga dapat memecahkan masalahmasalah kehidupan yang dihadapi baik di sekolah maupun di masyarakat (Kenedi et al., 2019).

Berdasarkan kegiatan observasi yang dilaksanakan di SD Negeri 2 Peken Belayu sebgaai sekolah sasaran, salah satu masalah yang dihadapi adalah keterbatasan media pembelajaran yang dapat digunakan dalam pembelajaran daring. Keterbatasan media pembelajaran daring ini terutama untuk pelajaran Matematika, khususnya materi keliling dan luas bangun datar. Matematika adalah mata pelajaran yang cenderung bersifat abstrak karena berisikan simbol-simbol tertentu, sehingga memerlukan kesungguhan dan konsentrasi dalam memahaminya (Mustamid \& Raharjo, 2015; Nurzazili et al., 2018; Umam \& Yudi, 2016). Pemaparan materi Matematika hanya berfokus pada buku pegangan siswa saja, tanpa penjelasan langsung dari guru di sekolah. Sehingga siswa semakin sulit untuk memahami materi yang dipelajari dan hanya menghafal rumus-rumus yang terdapat di buku tanpa memahami cara menentukan rumus tersebut. Hal ini menyebabkan sebagian besar siswa menganggap Matematika sebagai pelajaran yang sulit dan menakutkan (Fauzy \& Nurfauziah, 2021; Huzaimah \& Risma, 2021; Istikomah \& Wahyuni, 2018). Apabila permasalahan-permasalahan tersebut tidak segera diselesaikan, maka akan memberikan dampak negatif yang lebih besar, diantaranya rendahnya motivasi belajar dan hasil belajar Matematika siswa, yang pada akhirnya akan bermuara pada tidak tercapainya tujuan pembelajaran yang telah ditetapkan.

Permasalahan-permasahan yang dipaparkan terdapat beberapa solusi yang dapat dijadikan jalan keluar, diantaranya memperbanyak inovasi media pembelajaran daring, terutama pada mata pelajaran Matematika. Penggunaan media pembelajaran dapat dijadikan perantara atau alat pembantu dalam menyampaikan materi pembelajaran yang abstrak menjadi lebih konkret agar lebih mudah dipahami siswa sekaligus dapat memupuk motivasi belajar siswa (Karo-Karo \& Rohani, 2018; Mawardi, 2018). Salah satu media yang dapat digunakan dalam pembelajaran daring adalah video pembelajaran. Video pembelajaran tergolong ke dalam media audio visual yang dapat merangsang sekaligus dua indera, yakni indera pengelihatan dan pendengaran, sehingga dapat meningkatkan konsentrasi dan ingatan siswa terhadap pembelajaran (Karlina \& Setiyadi, 2019). Penggunaan video sebagai media pembelajaran dapat dijadikan sebagai sumber infomasi penting yang dapat diamati langsung mengenai pengetahuan yang belum dipahami siswa (Suryansah \& Suwarjo, 2016). Pembelajaran Matematika dapat berjalan dengan lebih efektif dengan dibantu video pembelajaran yang berisikan materi pembelajaran secara rinci dan dapat diulang kembali apabila materi belum dimengerti (Kusumaningrum \& Wijayanto, 2020). Video pembelajaran juga mampu menyajikan materi pembelajaran menjadi lebih realistik, lebih konkret, serta dapat memberikan pengalaman belajar bagi siswa (Purwanti, 2015). Salah satunya adalah video digital storytelling yang telah dinyatakan efektif dan mampu menarik perhatian siswa dalam pembelajaran (Julianingsih \& Krisnawati, 2020). Kemudian, video pembelajaran berbasis Powerpoint yang telah dinyatakan efektif dan mampu menarik perhatian serta meningkatkan tingkat pemahaman siswa (Anwar et al., 2020). Selanjutnya, media video berbasis aplikasi Kinemaster yang telah dinyatakan efektif dan mampu memudahkan pehamanan siswa terhadap materi pembelajaran (S. Wulandari \& Rahma, 2021). Maka dari itu, dapat ditarik simpulan bahwa video pembelajaran menjadi pilihan yang sangat baik untuk digunakan media untuk mendukung pembelajaran daring dalam pembelajaran Matematika. 
Dalam penelitian ini peneliti mengembangan video pembelajaran dengan berbantuan aplikasi Powtoon yang berfokus pada mata pelajaran Matematika, khusunya materi keliling dan luas bangun datar di kelas IV sekolah dasar. Aplikasi Powtoon merupakan aplikasi berbasis web yang diakses secara online. Powtoon dapat menjadi pilihan dalam mengembangkan video pembelajaran yang menarik (Y. Wulandari et al., 2020). Aplikasi Powtoon menyediakan berbagai fitur yang menarik, diantaranya animasi kartun, animasi tangan, efek transisi, efek transisi, dan timeline yang mudah ditur (Anjarsari et al., 2020). Aplikasi ini juga ramah pengguna atau tergolong mudah untuk dioperasikan (Kafah et al., 2020). Video pembelajaran dengan berbantuan aplikasi Powtoon yang dikembangkan peneliti memiliki tampilan yang menarik, karena menampilkan berbagai gambar, animasi, GIF, efek transisi, background, dan warna yang selaras. Dengan tampilan yang menarik tentunya siswa menjadi lebih termotivasi untuk belajar dan tidak lagi beranggapan bahwa Matematika adalah mata pelajaran yang menakutkan. Berbagai permasalahan pembelajaran dapat diatasi dengan penyajian materi yang menarik (Erwin \& Yarmis, 2019). Selain itu, dilengkapi pula dengan backsound berupa musik yang ceria, teks penjelas dan suara dubber yang dapat mendukung serta memperjelas materi yang dipaparkan (Kafah et al., 2020). Hal tersebut menjadi keunggulan pengembangan video pembelajaran dengan berbantuan aplikasi Powtoon jika dibandingkan dengan aplikasi lainnya. Dalam penelitian ini terdapat pula inovasi dalam penyajian materi agar lebih konkret, yakni diawali dengan penyajian permasalahan-permasalahan yang dekat dengan kehidupan siswa dan berkaitan dengan materi yang akan dibahas. Pembelajaran Matematika tentunya penting untuk diawali dengan pengenalan sebuah masalah dalam situasi nyata agar lebih mampu mendalami materi yang diberikan (Nurlaily et al., 2019). Selain lebih memperdalam pemahaman penyajian permasalahan ini dapat memupuk motivasi belajar dan rasa ingin tahu siswa. Dalam pembelajaran daring siswa juga dapat dengan mudah mengakses video pembelajaran yang dikembangan karena dapat dibagikan melalui tautan.

Tujuan dari pelaksanaan penelitian ini adalah mengembangkan sebuah produk, yaitu media pembelajaran berupa video pembelajaran berbantuan aplikasi Powtoon pada mata pelajaran Matematika, khususnya materi keliling dan luas bangun datar di kelas IV SD negeri 2 Peken Belayu. Dengan pelaksanaan penelitian ini dapat menjadi salah satu bentuk inovasi yang menjawab keterbatasan media pembelajaran yang dapat digunakan untuk mendukung pembelajaran daring, khususnya pada mata pelajaran Matematika. Selain itu, penelitian pengembangan ini juga memberikan dampak positif terhadap permasalahan yang dihadapi siswa dalam pembelajaran Matematika. Salah satunya siswa akan lebih mampu untuk memahami materi Matematika yang cenderung abstrak dan sulit dibayangkan, karena penyajian atau visualisasi materi yang lebih konkret dan menarik dengan diawali penyajian permasalahan yang dekat dengan kehidupan siswa, serta didukung kembali dengan penjelasan teks dan suara dubber. Siswa juga tidak akan menganggap Matematika sebagai pelajaran yang sulit dan menakutkan karena tampilan video yang menarik yang dapat menciptakan suasana belajar menyenangkan, sekaligus meningkatkan motivasi belajar siswa.

\section{METODE}

Jenis penelitian ini merupakan penelitian dan pengembangan atau dikenal juga dengan istilah Research and Development (R \& D). Penelitian pengembangan merupakan penelitian yang memiliki tujuan untuk menghasilkan suatu produk, baik berupa media pembelajaran, model, bahan ajar, dan lain sebagainya. Produk yang kembangkan sesuai dengan kebutuhan dan keperluan untuk masalah-masalah yang benar-benar terjadi di lapangan, sehingga produk yang dihasilkan dalam penelitian pengembangan dapat menjadi solusi bagi masalahmasalah tersebut. Dalam melaksanakan penelitian pengembangan terdapat beberapa model yang dapat dipilih peneliti. Pada penelitian ini model yang digunakan adalah model ADDIE. Penelitian pengembangan berdasarkan model ADDIE terdiri atas lima tahapan. Adapun ilustrasi tahapan model ADDIE dapat dilihat pada Gambar 1. Subjek penelitian dalam pengembangan video pembelajaran ini adalah video pembelajaran berbantuan aplikasi Powtoon pada materi keliling dan luas bangun datar di kelas IV sekolah dasar. Video pembelajaran ini sebagai subjek penelitian akan diuji oleh ahli materi dan ahli media, yaitu dua orang dosen yang telah berkompeten dibidangnya. Selain itu, terdapat pula guru sebagai responden mengenai video pembelajaran yang telah dikembangkan. Pengujian ini dilakukan untuk mengetahui kelayakan dari video pembelajaran yang telah dikembangkan. 


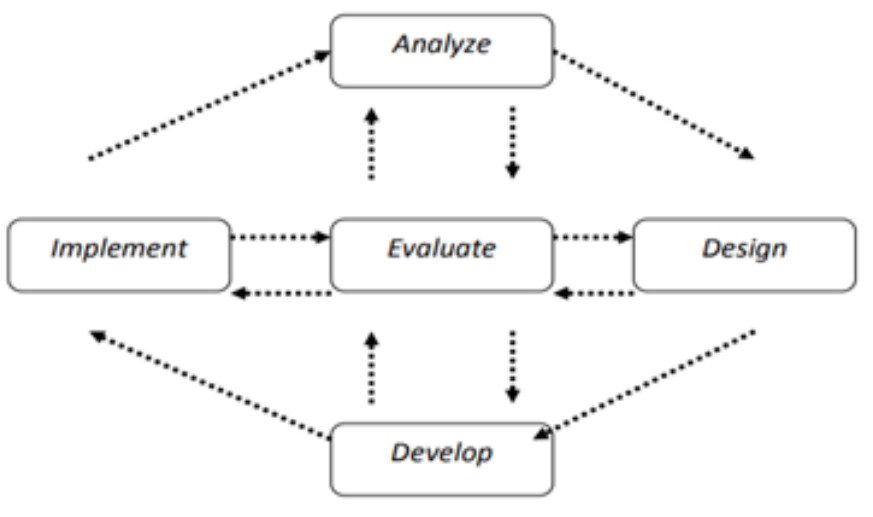

Gambar 1. Tahapan Model ADDIE (Sumber: Anglada (dalam Tegeh \& Kirna, 2013))

Metode pengumpulan data dalam penelitian ini adalah kuesioner semi tertutup, yakni perpaduan dari kuesioner terbuka dan tertutup. Kuesioner ini juga dapat diartikan sebagai suatu alat yang digunakan untuk mengumpulkan data hasil uji yang dilakukan para ahli dan guru sebagai subjek penelitian. Kuesioner ini berisikan kumpulan pertanyaan atau pernyataan mengenai video pembelajaran yang dibuat oleh peneliti. Gambaran awal instrumen atau kisi-kisi instrumen yang dalam penelitian ini dapat dilihat pada Tabel 1., Tabel 2., dan Tabel 3. Metode analisis data berisikan cara penggunaan statistik yang digunakan untuk keperluan penelitian. Dalam penelitian ini peneliti menggunakan analisis data kuantitatif dan analisis data kualitatif. Teknik analisis kualitatif pada penelitian ini digunakan untuk mengolah data hasil uji ahli media, ahli materi dan juga respon guru yang berupa informasi-informasi dari yang bersifat kualitatif, seperti masukan, kritik, maupun tanggapan yang diberikan. Sedangkan, analisis data kuantitatif pada penelitian ini digunakan untuk mengolah data yang diperoleh dari kuesioner ke dalam bentuk persentase. Setelah mendapatkan hasil uji dalam bentuk persentase, ditafsirkan kembali ke dalam beberapa kriteria kualitatif yang dapat dilihat pada Tabel 4 .

Tabel 1. Kisi-kisi Instrumen untuk Ahli Media

\begin{tabular}{|c|c|c|c|c|c|}
\hline No & Variabel & & Sub Variabel & $\begin{array}{c}\text { Jumlah } \\
\text { Butir }\end{array}$ & Nomor Butir \\
\hline \multirow[t]{3}{*}{1.} & Teks & 1) & Komposisi teks pada screen sesuai & 1 & 1 \\
\hline & & 2) & Tipe, ukuran, dan warna sesuai & 3 & $2,3,4$ \\
\hline & & 3) & Keterbacaan teks jelas & 1 & 5 \\
\hline \multirow[t]{4}{*}{2.} & Visual & 1) & Gambar sesuai dengan materi & 1 & 6 \\
\hline & & 2) & $\begin{array}{l}\text { Setiap gambar yang ditampilkan kualitasnya } \\
\text { sesuai }\end{array}$ & 1 & 7 \\
\hline & & 3) & Pemilihan background & 1 & 8 \\
\hline & & 4) & Proporsi warna & 1 & 9 \\
\hline \multirow[t]{5}{*}{3.} & Audio & 1) & Ketepatan audio dengan materi & 1 & 10 \\
\hline & & 2) & Kejelasan unsur audio & 1 & 11 \\
\hline & & 3) & Kualitas audio yang digunakan & 1 & 12 \\
\hline & & 4) & Suara dubber selaras dengan teks dan grafis & 2 & 13,14 \\
\hline & & 5) & Kejelasan suara dubber & 1 & 15 \\
\hline \multirow[t]{3}{*}{4.} & Audio Visual & 1) & Unsur animasi sesuai dengan materi & 1 & 16 \\
\hline & & 2) & Animasi yang ditampilkan menarik & 1 & 17 \\
\hline & & 3) & Kualitas animasi telah sesuai & 1 & 18 \\
\hline
\end{tabular}

Tabel 2. Kisi-kisi Instrumen untuk Ahli Materi

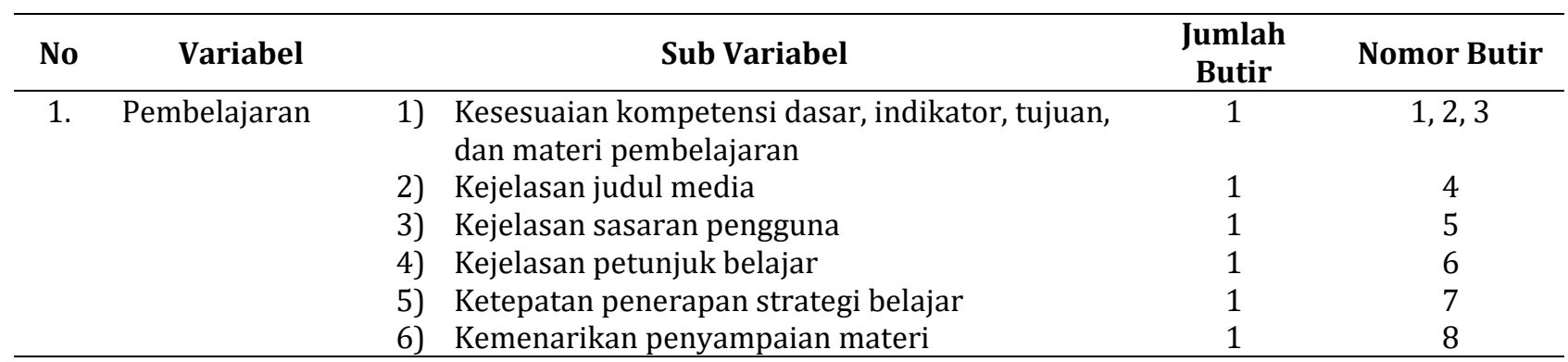




\begin{tabular}{|c|c|c|c|c|c|}
\hline No & & Variabel & Sub Variabel & $\begin{array}{c}\text { Jumlah } \\
\text { Butir }\end{array}$ & Nomor Butir \\
\hline \multirow[t]{10}{*}{2.} & Isi & & Keterpaduan materi & 1 & 9 \\
\hline & & 2) & Kedalaman materi & 1 & 10 \\
\hline & & 3) & Kejelasan isi materi & 1 & 11 \\
\hline & & 4) & Urutan materi & 1 & 12 \\
\hline & & 5) & Kejelasan contoh yang disertakan & 1 & 13 \\
\hline & & 6) & Kecukupan contoh yang dijelaskan & 1 & 14 \\
\hline & & 7) & Kejelasan bahasa yang digunakan & 1 & 15 \\
\hline & & 8) & Kesesuaian bahasa dengan sasaran pengguna & 1 & 16 \\
\hline & & 9) & Kejelasan informasi pada ilustrasi gambar & 1 & 17 \\
\hline & & 10) & Kejelasan informasi pada ilustrasi animasi & 1 & 18 \\
\hline
\end{tabular}

Tabel 3. Kisi-kisi Instrumen untuk Guru

\begin{tabular}{|c|c|c|c|c|c|}
\hline No & Variabel & & Sub Variabel & $\begin{array}{l}\text { Jumlah } \\
\text { Butir }\end{array}$ & Nomor Butir \\
\hline \multirow[t]{9}{*}{1.} & Media & 1) & Keterbacaan teks & 1 & 1 \\
\hline & & 2) & Kejelasan ilustrasi & 1 & 2 \\
\hline & & 3) & Ketepatan proporsi warna & 1 & 3 \\
\hline & & 4) & Ketepatan pemilihan backround & 1 & 4 \\
\hline & & 5) & Kesesuaian sajian gambar & 1 & 5 \\
\hline & & 6) & Kesesuaian sajian animasi & 1 & 6 \\
\hline & & 7) & Kejelasan audio dan suara dubber & 2 & 7,8 \\
\hline & & 8) & $\begin{array}{l}\text { Keselarasan suara dubber dengan teks dan } \\
\text { grafis }\end{array}$ & 2 & 9,10 \\
\hline & & 9) & Kemenarikan media & 1 & 11 \\
\hline \multirow[t]{7}{*}{2.} & Materi & 1) & $\begin{array}{l}\text { Keterhubungan kompetensi dasar, indikator, } \\
\text { tujuan, dan materi }\end{array}$ & 1 & 12 \\
\hline & & 2) & Ketepatan penggunaan bahasa & 1 & 13 \\
\hline & & 3) & Kejelasan urutan materi yang disajikan & 1 & 14 \\
\hline & & 4) & $\begin{array}{l}\text { Kesesuaian materi dengan tingkat kemampuan } \\
\text { siswa }\end{array}$ & 1 & 15 \\
\hline & & 5) & Kemenarikan penyajian materi & 1 & 16 \\
\hline & & 6) & $\begin{array}{l}\text { Ketepatan contoh yang diberikan dengan } \\
\text { materi }\end{array}$ & 1 & 17 \\
\hline & & 7) & $\begin{array}{l}\text { Kecukupan contoh yang diberikan dengan } \\
\text { materi }\end{array}$ & 1 & 18 \\
\hline
\end{tabular}

Tabel 4. Range Persentase dan Kriteria Kelayakan Produk

\begin{tabular}{cccc}
\hline No & Interval & Kualifikasi & Kriteria Kelayakan \\
\hline 1 & $81 \% \leq$ skor $\leq 100 \%$ & Sangat baik & Sangat layak, tidak perlu revisi \\
2 & $61 \% \leq$ skor $\leq 80 \%$ & Baik & Layak, tidak perlu revisi \\
3 & $41 \% \leq$ skor $\leq 60 \%$ & Cukup & Cukup layak, perlu revisi \\
4 & $21 \% \leq$ skor $\leq 40 \%$ & Kurang baik & Kurang layak, perlu revisi \\
5 & $0 \% \leq$ skor $\leq 20 \%$ & Sangat kurang & Tidak layak, perlu revisi \\
\hline
\end{tabular}

\section{HASIL DAN PEMBAHASAN}

Hasil

Penelitian pengembangan ini menghasilkan produk berupa video pembelajaran berbantuan aplikasi Powtoon pada pembelajaran Matematika, khususnya materi keliling dan luas bangun datar di kelas IV sekolah dasar. Pengembangan video pembelajaran berbantuan Powtoon ini menggunakan model pengembangan ADDIE. Penelitian pengembangan berdasarkan model ADDIE terdiri atas lima tahapan, yaitu analisis (analyze), perancangan (design), pengembangan (develop), implementasi (implement), dan evaluasi (evaluate). Tahap analisis (analyze). Pada tahap ini peneliti menganalisis mengenai perlunya pengembangan suatu produk pendidikan di SD Negeri 2 Peken Belayu. Perlunya pengembangan dilatar belakangi oleh beberapa masalah, yang menyebabkan produk tersebut tidak lagi relevan dengan kebutuhan di lapangan. Pengembangan produk tersebutlah nantinya yang akan menjawab atau menjadi solusi dari masalah dan kebutuhan di lapangan. Adapun beberapa hal yang dianalisis peneliti dalam tahap ini, antara lain kebutuhan pembelajaran, karakteristik siswa, 
dan kurikulum yang berlaku. Setelah melaksanakan tahap analisis, antara lain peneliti menemukan fakta bahwa terdapat kekurangan atau keterbatasan media pembelajaran yang dapat digunakan dalam pembelajaran berbasis daring, khususnya pada mata pelajaran Matematika, yang sebenarnya sangat memerlukan bantuan media pembelajaran karena memiliki objek yang cenderung bersifat abstrak. Maka dari itu, peneliti harus mengembangkan produk yang sesuai dengan kebutuhan tersebut. Peneliti menemukan adanya anggapan Matematika sebagai mata pelajaran yang sulit dan menakutkan bagi siswa. Selain itu, siswa juga memiliki tingkat pemahaman yang kurang dalam pembelajaran Matematika, sehingga motivasi belajar Matematika juga rendah. Adapun kurikulum yang berlaku di SD Negeri 2 Peken Belayu ini adalah kurikulum 2013, baik dari kelas I hingga kelas VI. Maka dari itu, produk yang dikembangkan harus disesuaikan dengan kurikulum 2013, baik dari segi materi, kompetensi inti, kompetensi dasar, tujuan, dan lain sebagainya. Kompetensi dasar berdasarkan kurikulum 2013, yaitu menjelaskan dan menentukan keliling dan luas daerah persegi, dan segitiga. Sedangkan indikator pencapaiannya, terdiri atas mengidentifikasi berbagai bangun datar persegi, persegi panjang, dan segitiga; menentukan keliling persegi, persegi panjang, dan segitiga; serta menentukan luas persegi, persegi panjang, dan segitiga.

Tahap perancangan (design). Pada tahap ini dilakukan perancangan kerangka awal produk yang ingin dikembangkan setelah menelaah berbagai masalah yang ditemukan pada tahap analisis, yakni berupa storyboard dari video pembelajaran yang akan dikembangkan secara sistematis. Dalam tahap perancangan ini peneliti juga menentukan software atau aplikasi yang akan digunakan dalam membuat video pembelajaran, yakni aplikasi Powtoon yang akhirnya dipilih sebagai aplikasi utama dan Filmora sebagai aplikasi pendukung dalam melakukan proses editing. Peneliti memilih aplikasi ini setelah mempertimbangkan beberapa hal, baik dari segi fitur, animasi, cara pengoperasian, biaya yang diperlukan dan lain sebagainya. Selain itu, juga dilakukan penentuan atau pengumpulan komponen-komponen yang dibutuhkan dalam pengembangan video pembelajaran, baik dari segi materi pembelajaran yang akan dipaparkan, gambar, animasi, background, backsound, GIF, dan berbagai komponen lainnya yang diperlukan pada proses pengembangan video pembelajaran. Tahap pengembangan (develop). Pada tahap pengembangan ini peneliti merealisasikan desain video pembelajaran atau storyboard yang telah dirancang pada tahap sebelumnya. Diawali dengan menyiapkan perangkat-perangkat yang diperlukan berupa PC atau komputer yang memiliki spesifikasi yang mumpuni, serta jaringan internet yang memadai. Kemudian dilanjutkan dengan tahap produksi dengan menyusun dan menggabungkan semua komponen video pembelajaran yang telah disiapkan sesuai dengan storyboard yang telah dirancang. Beberapa tampilan dari video pembelajaran berbantuan Powtoon yang dikembangkan dapat dilihat pada Gambar 2.
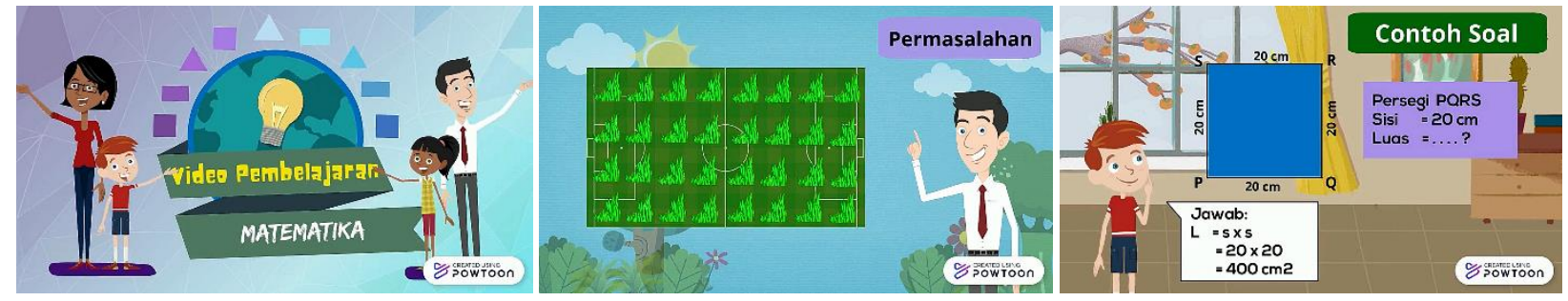

Gambar 2. Tampilan Video Pembelajaran

Selanjutnya, dilakukan uji validitas terhadap video pembelajaran yang telah dikembangkan peneliti oleh ahli materi, ahli media, serta guru sebagai responden. Kemudian, ditidaklanjuti dengan melakukan revisi terhadap video pembelajaran yang telah diuji apabila diperlukan. Setelah melewati tahap tersebut, video pembelajaran yang telah dianggap layak disebarluaskan secara lebih lanjut untuk mendukung proses belajar mengajar. Tahap implementasi (Implement). Pada tahap implementasi ini produk berupa video pembelajaran yang telah dikembangkan digunakan atau diterapkan secara langsung dalam kegiatan belajar mengajar di kelas. Namun, tahapan ini tidak dilaksanakan dalam pengembangan video pembelajaran berbantuan aplikasi Powtoon ini dikarenakan adanya keterbatasan dan hambatan yang dihadapi oleh peneliti. Tahap evaluasi (evaluate). Tahap evaluasi adalah tahapan penilaian terhadap kompetensi dan hasil belajar siswa, yang nantinya dapat dijadikan sebagai umpan balik dari produk yang telah dikembangkan dan diimplementasikan oleh peneliti dalam pembelajaran di kelas. Namun, pada penelitian ini hanya dilaksanakan evaluasi secara formatif, yaitu uji validitas produk oleh dua orang dosen sebagai ahli media dan ahli materi, serta seorang guru sebagai responden. Adapun hasil analisis uji validitas video pembelajaran berbantuan aplikasi Powtoon yang dikembangkan adalah sebagai berikut. Berdasarkan uji validitas terhadap video pembelajaran berbantuan aplikasi Powtoon yang dilaksanakan oleh ahli media pembelajaran diperoleh persentase validitas sebesar 97,7\%. Dari persentase yang didapat ditafsirkan kembali ke dalam beberapa kriteria kualitatif, menunjukkan bahwa video pembelajaran yang dikembangkan termasuk kedalam kualifikasi sangat baik, sehingga sudah layak dan tidak perlu diadakan revisi kembali. Sedangkan, berdasarkan hasil uji validitas oleh ahli materi pembelajaran diperoleh persentase validitas sebesar 93,3\%. Dari persentase yang didapat, menunjukkan bahwa video pembelajaran yang dikembangkan 
termasuk kedalam kualifikasi sangat baik, sehingga sudah layak dan tidak perlu diadakan revisi kembali. Kemudian, berdasarkan hasil uji validitas yang dilaksanakan oleh guru diperoleh persentase validitas sebesar 96,6\%, menunjukkan bahwa video pembelajaran yang dikembangkan termasuk kedalam kualifikasi sangat baik, sehingga sudah layak dan tidak perlu diadakan revisi kembali. Dari hasil uji validitas yang dilaksanakan, dapat dimpulkan bahwa video pembelajaran berbantuan aplikasi Powtoon yang dikembangkan telah layak dan valid dengan kategori sangat baik.

Matematika adalah mata pelajaran yang cenderung bersifat abstrak karena berisikan simbol-simbol tertentu, sehingga memerlukan kesungguhan dan konsentrasi dalam memahaminya (Mustamid \& Raharjo, 2015; Nurzazili et al., 2018; Umam \& Yudi, 2016). Sehingga Matematika memerlukan sebuah media untuk menyajikan materi agar lebih konkret untuk dipahami siswa sekolah dasar. Video pembelajaran juga mampu menyajikan materi pembelajaran menjadi lebih realistik, lebih konkret, serta dapat memberikan pengalaman belajar bagi siswa (Purwanti, 2015). Video pembelajaran tentunya sangat cocok untuk dijadikan sebagai media pembelajaran Matematika. Dalam Aplikasi Powtoon dipilih peneliti dalam mengembangkan video pembelajaran karena memiliki banyak kelebihan. Aplikasi Powtoon menyediakan berbagai fitur yang menarik, diantaranya animasi kartun, animasi tangan, efek transisi, efek transisi, dan timeline yang mudah ditur (Anjarsari et al., 2020). Oleh karena itu, dengan video pembelajaran berbantuan aplikasi Powtoon yang dikembangkan, materi Matematika dapat dituangkan secara lebih konkret dan menarik, sehingga lebih mudah untuk dipahami sekaligus dapat meningkatkan motivasi belajar siswa.

Video pembelajaran berbantuan Powtoon yang dikembangkan juga memiliki beberapa keunggulan dalam menunjang proses belajar mengajar. Salah satu keunggulan dari video pembelajaran berbantuan aplikasi Powtoon yang dikembangkan adalah memiliki tampilan yang menarik dan menciptakan suasana belajar yang menyenangkan bagi siswa, karena menampilkan berbagai gambar, animasi, GIF, efek transisi, background, dan warna yang selaras. Dengan tampilan yang menarik tentunya siswa menjadi lebih termotivasi untuk belajar dan tidak lagi beranggapan bahwa Matematika adalah mata pelajaran yang menakutkan (Y. Wulandari et al., 2020). Berbagai permasalahan pembelajaran dapat diatasi dengan penyajian materi yang menarik (Erwin \& Yarmis, 2019). Selain itu, video pembelajaran berbantuan aplikasi Powtoon ini juga dilengkapi dengan backsound berupa musik yang ceria, teks penjelas dan suara dubber yang dapat mendukung serta memperjelas materi yang dipaparkan (Kafah et al., 2020). Keunggulan lainnya adalah penyajian materi dalam video pembelajaran berbantuan aplikasi Powtoon ini dikemas lebih konkret dengan diawali permasalahan-permasalahan yang terjadi disekitar siswa. Pembelajaran Matematika tentunya penting untuk diawali dengan pengenalan sebuah masalah dalam situasi nyata agar lebih mampu mendalami materi yang diberikan (Nurlaily et al., 2019). Sehingga dengan penyajian permasalahan ini siswa lebih mampu memahami materi Matematika yang memiliki objek abstrak dan sulit dibayangkan oleh siswa. Kemudian dari segi pengoperasian atau penggunaan video pembelajaran ini sebagai media pembelajaran juga tidak sulit (Kafah et al., 2020). Video pembelajaran yang dikembangkan juga dapat dengan mudah diakses siswa melalui tautan. Oleh karena itu, video pembelajaran berbantuan Powtoon ini layak digunakan untuk menunjang kegiatan belajar mengajar.

Penelitian ini didukung oleh penelitian-penelitian lainnya, salah satunya penelitian yang dilaksanakan sebelumnya mengenai media pembelajaran berbasis Powtoon dinyatakan mempunyai dampak efektifitas yang sangat baik terhadap antusias dan dapat menarik minat belajar peserta didik (Andrianti et al., 2016). Kemudian, penelitian ini juga didukung penelitian mengenai aplikasi Powtoon dinyatakan efektif dan juga menarik untuk dijadikan media pembelajaran karena mempunyai keunggulan dalam fitur animasi (Astika et al., 2019). Selanjutnya, penelitian yang dilaksanakan mengenai video animasi pembelajaran berbasis Powtoon dinyatakan valid dengan kriteria sangat baik untuk dijadikan media pembelajaran karena sifatnya yang menarik, terkesan lucu, sehingga cocok untuk siswa di sekolah dasar (Nuswantoro \& Wicaksono, 2019). Sedangkan, penelitian mengenai video berbasis aplikasi Powtoon dinyatakan telah valid dengan berbagai animasi menarik dan mampu memperdalam pemahaman siswa terhadap materi pembelajaran yang diberikan (Kafah et al., 2020). Berdasarkan penelitian-penelitian tersebut, dapat disimpulkan bahwa video pembelajaran berbantuan aplikasi Powtoon dinyatakan efektif dan layak untuk menunjang proses belajar mengajar, karena siswa lebih mampu memahami materi sekaligus lebih termotivasi dalam belajar. Penelitian ini tentunya memberikan implikasi, terutama di bidang pendidikan. Adapun beberapa implikasi yang ditimbulkan dalam pengembangan video pembelajaran berbantuan aplikasi Powtoon ini, diantaranya kepada sekolah dapat menggunakan referensi dan acuan pelaksanaan kegiatan belajar mengajar dalam rangka peningkatan mutu di tingkat sekolah. Kepada guru dapat dijadikan inspirasi dalam berinovasi terkait media pembelajaran daring dan sebagai sarana dalam melaksanakan kegiatan belajar mengajar. Selanjutnya, kepada siswa dapat dijadikan sumber atau sarana belajar untuk memudahkan pemahaman terhadap materi pembelajaran, menciptakan suasana belajar yang menyenangkan, serta meningkatkan motivasi belajar, khusunya pembelajaran Matematika. 


\section{SIMPULAN}

Video pembelajaran berbantuan aplikasi Powtoon pada materi keliling dan bangun datar di kelas IV sekolah dasar yang dikembangkan termasuk kedalam kualifikasi sangat baik dan telah layak digunakan untuk menunjang proses belajar mengajar. Adapun saran yang ingin disampaikan, antara lain video pembelajaran berbantuan aplikasi Powtoon ini dapat dijadikan sebagai acuan pelaksanaan pembelajaran bagi sekolah, dapat dijadikan sebagai sarana untuk mendukung proses belajar mengajar bagi guru, dan sebagai sarana belajar agar lebih mudah memahami materi pembelajaran bagi siswa.

\section{DAFTAR PUSTAKA}

Abidin, Z., Hudaya, A., \& Anjani, D. (2020). Efektivitas Pembelajaran Jarak Jauh pada Masa Pandemi Covid-19. Journal of Education, October, 131-146. https://journal.lppmunindra.ac.id/index.php/RDJE/article/view/7659.

Agung, A. A. G. (2014). Buku Ajar Metodologi Penelitian Pendidikan. Aditya Media Publishing.

Andrianti, Y., Susanti, L. R. R., \& Hudaidah. (2016). Pengembangan Media Powtoon Berbasis Audiovisual Pada Pembelajaran Sejarah. Jurnal Criksetra, 5(9), 58-68. https://doi.org/10.36706/jc.v5i1.4802.

Anjarsari, E., Farisdianto, D. D., \& Asadullah, A. W. (2020). Pengembangan Media Audiovisual Powtoon pada Pembelajaran Matematika. JMPM: Jurnal Matematika Dan Pendidikan Matematika, 5(2), 40-50. https://doi.org/10.26594/jmpm.v5i2.2084.

Anugrahana, A. (2020). Hambatan, Solusi dan Harapan : Pembelajaran Daring Selama Masa Pandemi Covid-19 Oleh Guru Sekolah Dasar. Scholaria: Jurnal Pendidikan Dan Kebudayaan, 10(3), 282-289. https://ejournal.uksw.edu/scholaria/article/view/4033.

Anwar, Z., Kahar, M. S., Rawi, R. D. P., Nurjannah, N., Suaib, H., \& Rosalina, F. (2020). Development of Interactive Video Based Powerpoint Media In Mathematics Learning. Journal of Educational Science and Technology (EST), 6(2), 167. https://doi.org/10.26858/est.v6i2.13179.

Arsyad, A. (2015). Media Pembelajaran. PT Rajagrafindo Persada.

Astawa, I. N. T. (2017). Memahami Peran Masyarakat dan Pemerintah dalam Kemajuan Mutu Pendidikan Di Indonesia. Jurnal Penjaminan Mutu, 3(2), 197. https://doi.org/10.25078/jpm.v3i2.200.

Astika, R. Y., Anggoro, B. S., \& Andriani, S. (2019). Pengembangan Video Media Pembelajaran Matematika dengan bantuan Powtoon. Jurnal Pemikiran Dan Penelitian Pendidikan Matematika, 2(2), 85-96. http://dx.doi.org/10.36765/jp3m.v2i2.29.

Chang, T. Y., Hong, G., Paganelli, C., Phantumvanit, P., Chang, W. J., Shieh, Y. S., \& Hsu, M. L. (2020). Innovation of dental education during COVID-19 pandemic. Journal of Dental Sciences, 155. https://doi.org/10.1016/j.jds.2020.07.011.

Crismono, P. C. (2017). Pengaruh Outdoor Learning Terhadap Kemampuan Berpikir Kritis Matematis Siswa. Junal Pendidikan Matematika Dan Sains, 4(2), 106-113. https://doi.org/10.21831/jpms.v5i2.15482.

Erwin, V. A., \& Yarmis. (2019). Multimedia Interaktif Bermuatan Permainan Edukatif di Kelas V Sekolah Dasar. Jurnal Basicedu, 3(2), 901-908. https://doi.org/10.31004/basicedu.v3i3.183.

Fauzy, A., \& Nurfauziah, P. (2021). Kesulitan Pembelajaran Daring Matematika Pada Masa Pandemi Covid-19 di SMP Muslimin Cililin. Jurnal Cendekia: Jurnal Pendidikan Matematika, 5(1), 551-561. https://doi.org/10.31004/cendekia.v5i1.514.

Handayani, S. D., \& Irawan, A. (2020). Pembelajaran Matematika di Masa Pandemic Covid-19 Berdasarkan Pendekatan Matematika Realistik. Jurnal Math Educator Nusantara, 6(2), 179-189. https://doi.org/10.29407/jmen.v6i2.14813.

Hulukati, E., Achmad, N., \& Bau, M. A. (2021). Deskripsi Penggunaan Media E-Learning dalam Pembelajaran Matematika di Masa Pandemi Covid-19. Jambura Journal of Mathematics Education, 2(1), 21-27. https://doi.org/10.34312/jmathedu.v2i1.10061.

Huzaimah, P. Z., \& Risma, A. (2021). Hambatan yang Dialami Siswa Dalam Pembelajaran Daring Matematika Pada Masa Pandemi COVID-19. Jurnal Cendekia: Jurnal Pendidikan Matematika, 05(01), 533-541. https://jcup.org/index.php/cendekia/article/view/537.

Hwang, G. J., Wang, S. Y., \& Lai, C. L. (2020). Effects of a social regulation-based online learning framework on students' learning achievements and behaviors in mathematics. Computers and Education, 160, 104031. https://doi.org/10.1016/j.compedu.2020.104031.

Istikomah, E., \& Wahyuni, A. (2018). Student's Mathematics Anxiety on The Use of Technology in Mathematics Learning. JRAMathEdu (Journal of Research and Advances in Mathematics Education), 3(2), 69. https://doi.org/10.23917/jramathedu.v3i2.6364.

Julianingsih, D., \& Krisnawati, E. (2020). Efektivitas Video Digital Storytelling terhadap Hasil Belajar Siswa Kelas $\mathrm{X}$ Materi Trigonometri. Journal of Medives: Journal of Mathematics Education IKIP Veteran Semarang, 4(1), 129. https://doi.org/10.31331/medivesveteran.v4i1.975.

Kafah, A. N. K., Nulhakim, L., \& Pamungkas, A. S. (2020). Development of Video Learning Media Based on Powtoon 
Application on the Concept of the Properties of Light for Elementary School Students. Gravity: Jurnal Ilmiah Penelitian Dan Pembelajaran Fisika, 6(1), 34-40. https://doi.org/10.30870/gravity.v6i1.6825.

Karlina, N., \& Setiyadi, R. (2019). The Use of Audio-Visual Learning Media in Improving Student Concentration in Energy Materials. PRIMARYEDU: Journal of Elementary Education, 3(1), 17-26. https://doi.org/10.22460/pej.v3i1.1229.

Karo-Karo, I. R., \& Rohani. (2018). Manfaat Media dalam Pembelajaran. AXIOM, 7(1), 91-96. http://dx.doi.org/10.30821/axiom.v7i1.1778.

Kenedi, A. K., Helsa, Y., Ariani, Y., Melva, Z., \& Sherlyane, H. (2019). Mathematical Connection of Elementary School Students to Solve Mathematical Problems. Journal on Mathematics Education, 10(1), 69-79. https://doi.org/10.22342/jme.10.1.5416.69-80.

Kusumaningrum, B., \& Wijayanto, Z. (2020). Apakah Pembelajaran Matematika Secara Daring Efektif? (Studi Kasus pada Pembelajaran Selama Masa Pandemi Covid-19). Kreano, Jurnal Matematika Kreatif-Inovatif, 11(2), 139-146. http://dx.doi.org/10.15294/kreano.v11i2.25029.

Mawardi. (2018). Merancang Model dan Media Pembelajaran. Scholaria: Jurnal Pendidikan Dan Kebudayaan, 8(1), 26-40. https://doi.org/10.24246/j.js.2018.v8.i1.p26-40.

Megawanti, P. (2015). Meretas Permasalahan Pendidikan di Indonesia. Jurnal Formatif, 2(3), 227-234. http://dx.doi.org/10.30998/formatif.v2i3.105.

Mishra, L., Gupta, T., \& Shree, A. (2020). Online teaching-learning in higher education during lockdown period of COVID-19 pandemic. International Journal of Educational Research Open, June, 100012. https://doi.org/10.1016/j.ijedro.2020.100012.

Muhtadi, D., Sukirwan, Warsito, \& Prahmana, R. C. I. (2017). Sundanese Ethnomathematics: Mathematical Activities in Estimating, Measuring, and Making Patterns. Journal on Mathematics Education, 8(2), 185198. https://doi.org/10.22342/jme.8.2.4055.185-198.

Mustamid, \& Raharjo, H. (2015). Pengaruh Efektifitas Multimedia Pembelajaraan Macromedia Flash 8 Terhadap Motivasi Belajar Siswa Pada Materi Fungsi Komposisi Dan Invers. Eduma: Mathematics Education Learning and Teaching, 4(1). https://doi.org/10.24235/eduma.v4i1.21.

Nugrawati, U., Nuryakin, \& Afrilianto, M. (2018). Analisis Kesulitan Belajar pada Kemampuan Komunikasi Matematis Siswa MTs dengan Materi Segitiga Dan Segiempat. Jurnal Indomath: Indonesia MathematicsEducation, 2(1), 97-104. http://dx.doi.org/10.30738/indomath.v1i2.2543.

Nurlaily, V. A., Soegiyanto, H., \& Usodo, B. (2019). Elementary School Teacher's Obstacles in the Implementation of Problem-Based Learning Model in Mathematics Learning. Journal on Mathematics Education, 10(2), 229-238. https://doi.org/10.22342/jme.10.2.5386.229-238.

Nurzazili, Irma, A., \& Rahmi, D. (2018). Pengembangan Lembar Kegiatan Siswa (LKS) Berbasis Problem Based Learning (PBL) untuk Memfasilitasi Kemampuan Pemecahan Masalah Matematis Siswa di SMA Negeri 10 Pekanbaru. Jurnal Pendidikan Matematika, 2(1), 172-179. https://doi.org/10.31004/cendekia.v2i1.43.

Nuswantoro, D., \& Wicaksono, V. D. (2019). Pengembangan Media Video Animasi Powtoon "Hakan" pada Mata Pelajaran PPKn Materi Hak dan Kewajiban Siswa Kelas IV SDN Lidah Kulon IV Surabaya. JPGSD, 7(4), 3161-3170. pgsd/article/view/28270.

https://jurnalmahasiswa.unesa.ac.id/index.php/jurnal-penelitian-

Oyedotun, T. D. (2020). Sudden change of pedagogy in education driven by COVID-19: Perspectives and evaluation from a developing country. Research in Globalization, 2(June), 100029. https://doi.org/10.1016/j.resglo.2020.100029.

Purwanti, B. (2015). Pengembangan Media Video Pembelajaran Matematika dengan Model Assure. Jurnal Kebijakan Dan Pengembangan Pendidikan, 3(1), 42-47. https://doi.org/10.22219/jkpp.v3i1.2194.

Putria, H., Maula, L. H., \& Uswatun, D. A. (2020). Analisis Proses Pembelajaran dalam Jaringan (DARING) Masa Pandemi Covid- 19 Pada Guru Sekolah Dasar. Jurnal Basicedu, 4(4), 861-870. https://doi.org/10.31004/basicedu.v4i4.460.

Sahu, P. (2020). Closure of Universities Due to Coronavirus Disease 2019 (COVID-19): Impact on Education and Mental Health of Students and Academic Staff. Cureus, 2019(4), 4-9. https://doi.org/10.7759/cureus.7541.

Sugandi, A. I., Bernard, M., \& Linda. (2020). Efektivitas Pembelajaran Daring Berbasis Masalah Berbantuan Geogebra terhadap Kemampuan Penalaran Matematis di Era Covid-19. AKSIOMA: Jurnal Program Studi Pendidikan Matematika, 9(4), 993-1004. http://dx.doi.org/10.24127/ajpm.v9i4.3133.

Sumiati, A., \& Agustini, Y. (2020). Analisis Kesulitan Menyelesaikan Soal Segiempat dan Segitiga Siswa SMP Kelas VIII di Cianjur. Jurnal Pendidikan Matematika, 04(01), 321-330. https://doi.org/10.31004/cendekia.v4i1.184.

Suryansah, T., \& Suwarjo, S. (2016). Pengembangan Video Pembelajaran untuk Meningkatkan Motivasi Dan Hasil Belajar Kognitif Siswa Kelas IV SD. Jurnal Prima Edukasia, 4(2), 209. https://doi.org/10.21831/jpe.v4i2.8393. 
Tegeh, I. M., \& Kirna, I. M. (2013). Pengembangan Bahan Ajar Metode Penelitian Pendidikan dengan ADDIE Model. Jurnal IKA.

U.S, S. (2015). Arah Pendidikan di Indonesia dalam Tataran Kebijakan dan Implementasi. Formatif: Jurnal Ilmiah Pendidikan MIPA, 2(2), 111-121. https://doi.org/10.30998/formatif.v2i2.92.

Umam, K., \& Yudi. (2016). Pengaruh Menggunakan Software Macromedia Flash 8 Terhadap Hasil Belajar Matematika Siswa Kelas Viii. KALAMATIKA: Jurnal Pendidikan Matematika, 1(1), 84. https://doi.org/10.22236/kalamatika.vol1no1.2016pp84-92.

Wulandari, I. G. A. A., \& Agustika, G. N. S. (2020). Dramatik Pembelajaran Daring Pada Masa Pandemi Covid-19 (Studi Pada Persepsi Mahasiswa PGSD Undiksha). Mimbar PGSD Undiksha, 8(3), 515-526. http://dx.doi.org/10.23887/jjpgsd.v8i3.29259.

Wulandari, S., \& Rahma, I. F. (2021). Efektivitas Media Video KineMaster terhadap Hasil Belajar matematika Siswa Secara Daring Sri Wulandari. 7(1), 33-45. .

Wulandari, Y., Ruhiat, Y., \& Nulhakim, L. (2020). Pengembangan Media Video Berbasis Powtoon pada Mata Pelajaran IPA di Kelas V. Jurnal Pendidikan Sains Indonesia, 8(2), 269-279. https://doi.org/10.24815/jpsi.v8i2.16835. 